\title{
Maize Seed Quality in Response to Different Management Practices and Sites
}

\author{
E. T. Sebetha ${ }^{1}$, A. T. Modi $^{1} \&$ L. G. Owoeye ${ }^{2}$ \\ ${ }^{1}$ Crop Science, School of Agriculture, Earth and Environmental Sciences, University of KwaZulu-Natal, \\ Scottsville, South Africa \\ ${ }^{2}$ Agricultural Research Council-Institute for Industrial Crops, Rustenburg, South Africa \\ Correspondence: E. T. Sebetha, Crop Science, School of Agriculture, Earth and Environmental Sciences, \\ University of KwaZulu-Natal, Private Bag x 01, Scottsville 3209, South Africa. E-mail: \\ erick.sebetha@nwu.ac.za
}

\author{
Received: September 11, 2014 Accepted: November 2, 2014 Online Published: December 15, 2014 \\ doi:10.5539/jas.v7n1p215 URL: http://dx.doi.org/10.5539/jas.v7n1p215
}

\begin{abstract}
Maize seed quality during storage can decline to a level that may make the seed unacceptable for planting purpose. A factorial experiment randomized in complete block design with three replications was conducted during 2011/12 and 2012/13 planting seasons. The experiment comprised of three cropping systems (cowpea-maize rotation, monocropping maize and intercropped maize), three sites (Potchefstroom, Taung and Rustenburg) and two rates of nitrogen fertilizers applied in $\mathrm{kg} \mathrm{ha}^{-1}$ at each site ( 0 and 95 at Potchefstroom, 0 and 92 at Rustenburg, 0 and 113.5 at Taung). The experiment was conducted to investigate the effect of cropping system, site and nitrogen fertilization on maize seed quality. Maize seeds harvested from Potchefstroom and Rustenburg had significantly $(\mathrm{P}<0.05$ ) higher oil content of $4.4 \%$ than maize seeds harvested from Taung. Maize plots applied with nitrogen fertilizer had significantly $(\mathrm{P}<0.05)$ higher seeds protein content of $8.7 \%$ than maize plots without nitrogen fertilizer application. Maize seeds harvested from Potchefstroom had significantly $(\mathrm{P}<0.05)$ higher starch content of $71.8 \%$ than maize seeds harvested from Rustenburg and Taung. Cowpea-maize rotation and intercropped maize had significantly $(\mathrm{P}<0.05)$ higher seed phosphorus content of 0.50 and $0.52 \%$, respectively than monocropped maize. In this study, site as factor played a vital role on quality of maize seeds. Maize seed quality was improved significantly by the interaction effect of site $\mathrm{x}$ season.
\end{abstract}

Keyword: oil, phosphorus, protein, site, starch

\section{Introduction}

High seed quality is necessary to establish crops, therefore cultivated seed should have vigour and related physiological characters (Farshadfar et al., 2012). Maximum seed vigour is attained at harvest maturity and not at physiological maturity (Wambagu et al., 2012). Fertilizer applications led to a significant increase in seed vigour and viability. Protein quality is a relevant factor for producers and consumers, especially when grain quality determines the final price of the commodity (Da Silva et al., 2005). Quality characteristics in maize such as protein contents in seed is improved with optimum $\mathrm{N}$ level (Amanullah et al., 2009). Low and high nitrogen dose have adverse effect on quality of maize (Stone et al., 1998). Application of various $\mathrm{N}$ levels significantly influences seed protein content (Hammad et al., 2011). Without application of nitrogen, seed quality will extremely be decreased.

Nitrogen application at silking increases kernel crude protein content, up to the application of $100 \mathrm{~kg} \mathrm{ha}^{-1}$ nitrogen (Da Silva et al., 2005). This response showed that $\mathrm{N}$ applied during flowering is taken by the plant and accumulated in the grains. The advantage of increasing grain protein content with late $\mathrm{N}$-side dressing is reducing kernel susceptibility to breakage at harvesting, a feature that allows greater aggregation of commercial value to the product (Tsai et al., 1992). The quality of maize was improved by intercropping due to more nitrogen availability for maize in intercropping (Eskandari \& Ghanbari, 2009).

High oil maize contains higher energy content and more essential amino acids than conventional maize, which increases its value as animal feed (Lambert, 2001). The higher oil content of pollinator seed may influence seed germination and vigour. Seeds with high oil levels have often been associated with shorter longevity and greater 
deterioration than seeds with high starch content (Copeland \& Mc Donald, 2001). The inability of oily seed to imbibe moisture and hold it tightly causes additional water to become excessive quickly and may contribute to more rapid deterioration of oily seed compared to starchy seed at comparable moisture levels (Thomison et al., 2002). The major chemical component of the maize kernel is starch, which provide up to 72 to 73 percent of the kernel weight (Boyer \& Shannon, 1987). The composition of maize starch is genetically controlled. There is significant negative relationship between starch content and crude protein (Idikut et al., 2009). The crude protein decreases with increasing starch content of maize grain. Maize grown without fertilizer $\mathrm{N}$ promotes the greatest concentration of kernel starch, which has on average greater than kernels grown with the maximum $\mathrm{N}$ supply (Seebauer et al., 2010). Concentration of phosphorus in corn plants plays a critical role in intake of these nutrients by animal. Several studies have been done looking for the concentration of P in corn seed (Baker et al., 1970). The $P$ concentration in corn hybrids depends on its genetics and environments where it is grown (Gautam et al., 2011). Nitrogen fertilizer application reduces phosphorus content of maize and increases crude protein content significantly (Khogali et al., 2011).

Maize seed quality during previous studies was not extensively compared among intercropping and rotation in relation to nitrogen fertilization. These cropping systems were studied separately during previous studies. The hypothesis of the study was that, intercropping, cowpea-maize rotation and nitrogen fertilization will have no significant effect on maize seed quality. The interaction effect of site, cropping system, nitrogen and season on maize seed quality was evaluated in this study. The objective of this study was to determine the effect of cropping system, site, nitrogen fertilization and season on maize seed quality.

\section{Materials and Methods}

\subsection{Experimental Sites}

The study was conducted at three dryland sites in South Africa, namely the department of Agriculture experimental station in Taung situated at $27^{\circ} 30^{\prime} \mathrm{S}$ and $24^{\circ} 30^{\prime} \mathrm{E}$, Agriculture Research Council-Grain Crops Institute (ARC-GCI) experimental station in Potchefstroom situated at $27^{\circ} 26^{\prime} \mathrm{S}$ and $27^{\circ} 26^{\prime} \mathrm{E}$ and the Agricultural Research Council-Institute for Industrial Crops (ARC-IIC) experimental station in Rustenburg $25^{\circ} 43^{\prime} \mathrm{S}$ and $27^{\circ} 18^{\prime} \mathrm{E}$. The ARC-GCI experimental station has clay percentage of 34 and receives annual mean rainfall of $622.2 \mathrm{~mm}$, with daily temperature range of 9.1 to $25.2{ }^{\circ} \mathrm{C}$ during planting (Macvicar et al., 1977). The ARC-IIC experimental station has clay percentage of 49.5 and receives an annual mean rainfall of $661 \mathrm{~mm}$. Taung experimental site is situated in grassland savannah with annual mean rainfall of $1061 \mathrm{~mm}$ that begins in October. Potchefstroom (ARC-GCI) has plinthic catena soil, eutrophic, red soil widespread (Pule-Meulenberg et al., 2010). The soil at Taung is described as Hutton, deep, fine sandy dominated red freely drained, eutrophic with parent material that originated from Aeolian deposits (Staff, 1999). The soil at Rustenburg (ARC-IIC) has dark, olive grey and clay soil, bristle consistency, medium granular structure (Botha et al., 1968). The climatic data at three different sites during the course of the study were different as indicated on Table 1. 
Table 1. The mean temperature and rainfall data for Potchefstroom, Taung and Rustenburg for the duration of experimental period

\begin{tabular}{|c|c|c|c|c|c|c|c|c|c|c|}
\hline Site & Season & Climate data & Oct & Nov & Dec & Jan & Feb & Mar & Apr & May \\
\hline \multirow[t]{6}{*}{ Potch } & $2011 / 12$ & Rainfall (mm) & 35.58 & 66.29 & 75.95 & 19.05 & 33.78 & 66.29 & 4.32 & 0 \\
\hline & & $\operatorname{Max} \mathrm{T}\left({ }^{\circ} \mathrm{C}\right)$ & 28.64 & 29.45 & 28.57 & 30.42 & 29.11 & 28.72 & 25.00 & 25.00 \\
\hline & & $\operatorname{Min} \mathrm{T}\left({ }^{\circ} \mathrm{C}\right)$ & 11.19 & 13.78 & 15.81 & 16.22 & 16.30 & 13.59 & 8.05 & 5.17 \\
\hline & $2012 / 13$ & Rainfall (mm) & 21.84 & 13.46 & 42.42 & 45.72 & 28.7 & 43.94 & 47.5 & 8.14 \\
\hline & & $\operatorname{Max} \mathrm{T}\left({ }^{\circ} \mathrm{C}\right)$ & 29.01 & 30.21 & 27.99 & 30.11 & 31.03 & 28.43 & 24.32 & 22.61 \\
\hline & & $\operatorname{Min} \mathrm{T}\left({ }^{\circ} \mathrm{C}\right)$ & 12.43 & 14.62 & 15.41 & 16.81 & 15.5 & 14.58 & 9.12 & 3.86 \\
\hline \multirow[t]{6}{*}{ Taung } & $2011 / 12$ & Rainfall (mm) & 3.05 & 36.07 & 71.37 & 7.87 & 40.89 & 12.45 & 5.08 & 0.51 \\
\hline & & $\operatorname{Max} T\left({ }^{\circ} \mathrm{C}\right)$ & 31.05 & 33.28 & 32.8 & 36.12 & 32.87 & 32.96 & 28.02 & 27.65 \\
\hline & & $\operatorname{Min} \mathrm{T}\left({ }^{\circ} \mathrm{C}\right)$ & 9.25 & 10.6 & 14.79 & 16.19 & 17.01 & 13.75 & 8.24 & 4.48 \\
\hline & $2012 / 13$ & Rainfall (mm) & 0.25 & 8.89 & 14.99 & 40.89 & 32.00 & 14.2 & 9.2 & 8.4 \\
\hline & & $\operatorname{Max} \mathrm{T}\left({ }^{\circ} \mathrm{C}\right)$ & 32.5 & 34.98 & 32.86 & 36.29 & 31.5 & 31.8 & 27.3 & 26.8 \\
\hline & & $\operatorname{Min} \mathrm{T}\left({ }^{\circ} \mathrm{C}\right)$ & 10.74 & 14.27 & 15.71 & 17.83 & 17.7 & 15 & 9.4 & 6.2 \\
\hline \multirow[t]{6}{*}{ Rust } & $2011 / 12$ & Rainfall (mm) & 23.37 & 49.79 & 47.24 & 19.3 & 6.35 & 27.94 & 6.6 & 0.25 \\
\hline & & $\operatorname{Max} \mathrm{T}\left({ }^{\circ} \mathrm{C}\right)$ & 28.68 & 30.18 & 28.28 & 30.20 & 30.95 & 29.00 & 25.04 & 25.13 \\
\hline & & $\operatorname{Min} \mathrm{T}\left({ }^{\circ} \mathrm{C}\right)$ & 11.71 & 14.91 & 17.00 & 15.34 & 17.21 & 14.37 & 9.34 & 6.58 \\
\hline & $2012 / 13$ & Rainfall (mm) & 21.08 & 25.91 & 48.01 & 37.34 & 20.58 & 10.92 & 46.48 & 0 \\
\hline & & $\operatorname{Max} \mathrm{T}\left({ }^{\circ} \mathrm{C}\right)$ & 28.28 & 29.95 & 28.13 & 29.9 & 31.05 & 29.05 & 25.48 & 23.23 \\
\hline & & $\operatorname{Min} \mathrm{T}\left({ }^{\circ} \mathrm{C}\right)$ & 12.82 & 14.76 & 16.14 & 17.38 & 16.28 & 14.67 & 10.17 & 4.68 \\
\hline
\end{tabular}

Potch $=$ Potchefstroom, Rust $=$ Rustenburg, Max T $\left({ }^{\circ} \mathrm{C}\right)=$ Maximum temperature in decrees Celsius, Min T $\left({ }^{\circ} \mathrm{C}\right)$ $=$ Minimum temperature in decrees Celsius, $\mathrm{mm}=$ millimetres.

\subsection{Experimental Design}

The experiment was established in 2010/11 planting season and data considered for experiment was collected during 2011/12 and 2012/13 planting seasons. The experimental design was factorial experiment laid out in Random Complete Block Design (RCBD) with three replicates. The experiment consisted of three cropping systems (monocropping, rotational and intercropping), three locations Potchefstroom, Taung and Rustenburg and two levels of nitrogen fertilizer at each site, which were the amount of 0 and 95; 0 and 92;0 and $113.5 \mathrm{~kg} \mathrm{~N} \mathrm{ha}^{-1}$ applied on maize plots at Potchefstroom, Rustenburg and Taung respectively. Maize cultivar (PAN 6479) and cowpea (Bechuana white) were used as test crop.

\subsection{Chemical and Data Analysis}

The seeds of maize were collected during harvest maturity and were analysed using Near Infrared Reflectance Grain Analyser (NIR) at ARC-GCI food quality laboratory. The seeds were analysed for starch, protein and oil content. The seeds were sent to ARC-IIC for analysis of phosphorus content. The method used to analyse phosphorus content at ARC-IIC laboratory was micro-kjeldahl digestion process. Analysis of variance was performed using GenStat $14^{\text {th }}$ edition (2012). Least significant difference (LSD) was used to separate means. A probability level of less than 0.05 was considered as significant statistically (Gomez \& Gomez, 1984).

\section{Results}

\subsection{Maize Seed Oil Content}

Maize seed oil content was significantly affected $(\mathrm{P}<0.001)$ by the effect of site (Table 2$)$. Maize seeds harvested at Potchefstroom and Rustenburg had significantly $(\mathrm{P}<0.05)$ higher oil content of $4.4 \%$ than maize seeds harvested from Taung. Maize seed oil content was significantly $(\mathrm{P}<0.001)$ affected by the interaction of site $\mathrm{x}$ season and the interaction of site $\mathrm{x}$ nitrogen $\mathrm{x}$ season. Maize seed oil content was also significantly $(\mathrm{P}<$ 0.001 ) affected by the interaction of cropping system $\mathrm{x}$ site $\mathrm{x}$ nitrogen $\mathrm{x}$ season. 
Table 2. The interaction effects of cropping system, nitrogen fertilizer, site and season on maize seed oil content in percentages

\begin{tabular}{lllllll}
\hline \multirow{2}{*}{ Cropping system } & \multirow{2}{n}{ Site } & \multicolumn{2}{c}{ N-fertilization } & & \multicolumn{2}{c}{ Zero-N } \\
\cline { 3 - 4 } \cline { 5 - 6 } \cline { 5 - 6 } Intercropping & & $2011 / 12$ & $2012 / 13$ & & $2011 / 12$ & $2012 / 13$ \\
& Potch & 4.4 & 4.4 & & 4.2 & 4.5 \\
& Rust & 4.3 & 4.5 & & 4.4 & 4.2 \\
Monocropping & Taung & 4.4 & 4.0 & & 4.3 & 3.9 \\
& Potch & 4.2 & 4.5 & & 4.5 & 4.3 \\
& Rust & 4.4 & 4.6 & & 4.3 & 4.5 \\
Rotation & Taung & 4.3 & 3.8 & & 4.1 & 4.2 \\
& Potch & 4.2 & 4.6 & & 4.4 & 4.3 \\
& Rust & 4.3 & 4.5 & & 4.4 & 4.6 \\
SEM & Taung & 4.4 & 3.7 & & 4.3 & 4.1 \\
LSD (0.05) & 0.09 & & & & \\
\hline
\end{tabular}

$\mathrm{N}$-fert $=$ Nitrogen fertilization, Zero-N $=$ Zero nitrogen fertilizer, Potch $=$ Potchefstroom, Rust $=$ Rustenburg, $\mathrm{SEM}=$ standard error of means, $\mathrm{LSD}=$ least significant difference.

\subsection{Maize Seed Protein Content}

Maize seed protein content was significantly affected $(\mathrm{P}<0.001)$ by the effect of site (Table 3$)$. Maize seeds harvested from Taung had significantly $(\mathrm{P}<0.05)$ higher protein content of $8.8 \%$ than maize seeds harvested from Potchefstroom and Rustenburg. Application of nitrogen fertilizer had significant effect $(\mathrm{P}<0.001)$ on maize seed protein content. Maize plots applied with nitrogen fertilizer had significantly $(\mathrm{P}<0.05)$ higher seeds protein content of $8.7 \%$ than maize plots without nitrogen fertilizer application. Maize seed protein was also significantly $(\mathrm{P}<0.001)$ affected by seasonal effect. Maize seeds harvested during 2012/13 planting season had significantly $(\mathrm{P}<0.05)$ higher seed protein content of $8.7 \%$ than maize seeds harvested during $2011 / 12$ planting season. Maize seed protein content was significantly affected $(\mathrm{P}<0.001)$ by the interaction of site $\mathrm{x}$ nitrogen $(\mathrm{P}$ $=0.013)$ and the interaction of site $\mathrm{x}$ season.

Table 3. The interaction effects of cropping system, nitrogen fertilizer, site and season on maize seed protein content in percentages

\begin{tabular}{lllllll}
\hline \multirow{2}{*}{ Cropping system } & \multirow{2}{*}{ Site } & \multicolumn{2}{c}{ N-fertilization } & & \multicolumn{2}{c}{ Zero-N } \\
\cline { 3 - 4 } \cline { 6 - 7 } \cline { 5 - 6 } Intercropping & Potch & 7.4 & 9.6 & & 6.5 & 8.8 \\
& Rust & 8.5 & 8.6 & & 8.0 & 9.6 \\
& Taung & 8.5 & 9.5 & & 7.7 & 8.8 \\
Monocropping & Potch & 7.3 & 9.6 & & 6.0 & 7.4 \\
& Rust & 8.5 & 7.2 & & 7.8 & 6.9 \\
& Taung & 8.7 & 8.9 & & 8.4 & 9.6 \\
Rotation & Potch & 8.3 & 10.5 & & 5.9 & 8.2 \\
& Rust & 9.0 & 7.8 & & 7.7 & 6.7 \\
& Taung & 9.1 & 9.1 & & 7.7 & 9.9 \\
SEM & 0.59 & & & & \\
LSD (0.05) & 1.67 & & & & \\
\hline
\end{tabular}

$\mathrm{N}$-fert $=$ Nitrogen fertilization, Zero-N $=$ Zero nitrogen fertilizer, Potch $=$ Potchefstroom, Rust $=$ Rustenburg, $\mathrm{SEM}=$ standard error of means, $\mathrm{LSD}=$ least significant difference. 


\subsection{Maize Seed Starch Content}

Maize seed starch content was significantly affected $(\mathrm{P}<0.001)$ by site effect (Table 4$)$. Maize seeds harvested from Potchefstroom had significantly $(\mathrm{P}<0.05)$ higher starch content of $71.8 \%$ than maize seeds harvested from Rustenburg and Taung. Maize seed starch content was significantly affected $(\mathrm{P}<0.001)$ seasonal effect. Maize seeds harvested during 2011/12 planting season had significantly $(\mathrm{P}<0.05)$ higher starch content of $72.0 \%$ than maize seeds harvested during 2012/13 planting season. Maize seeds starch content was significantly affected (P $=0.037$ ) by the interaction of nitrogen $\mathrm{x}$ season.

Table 4. The interaction effects of cropping system, nitrogen fertilizer, site and season on maize seed starch content in percentages

\begin{tabular}{|c|c|c|c|c|c|}
\hline \multirow{2}{*}{ Cropping system } & \multirow{2}{*}{ Site } & \multicolumn{2}{|c|}{$\mathrm{N}$-fertilization } & \multicolumn{2}{|c|}{ Zero-N } \\
\hline & & $2011 / 12$ & $2012 / 13$ & $2011 / 12$ & $2012 / 13$ \\
\hline \multirow[t]{3}{*}{ Intercropping } & Potch & 73.0 & 71.0 & 73.2 & 69.5 \\
\hline & Rust & 71.4 & 68.5 & 71.4 & 68.6 \\
\hline & Taung & 71.5 & 69.8 & 71.9 & 69.8 \\
\hline \multirow[t]{3}{*}{ Monocropping } & Potch & 73.0 & 70.2 & 73.1 & 71.4 \\
\hline & Rust & 70.9 & 68.7 & 71.7 & 70.0 \\
\hline & Taung & 71.3 & 70.3 & 71.8 & 69.0 \\
\hline \multirow[t]{3}{*}{ Rotation } & Potch & 72.1 & 71.2 & 73.3 & 70.3 \\
\hline & Rust & 71.4 & 69.7 & 71.9 & 70.2 \\
\hline & Taung & 71.0 & 70.7 & 71.9 & 68.6 \\
\hline SEM & 0.59 & & & & \\
\hline $\operatorname{LSD}(0.05)$ & 0.14 & & & & \\
\hline
\end{tabular}

$\mathrm{N}$-fert $=$ Nitrogen fertilization, Zero-N $=$ Zero nitrogen fertilizer, Potch $=$ Potchefstroom, Rust $=$ Rustenburg, $\mathrm{SEM}=$ standard error of means, $\mathrm{LSD}=$ least significant difference.

\subsection{Maize Seed Phosphorus Content}

Cropping system had significant effect $(\mathrm{P}=0.05)$ on maize seed phosphorus content (Table 5). Cowpea-maize rotation and intercropped maize had significantly $(\mathrm{P}<0.05)$ higher seed phosphorus content of 0.50 and $0.52 \%$ respectively than monocropped maize. Application of nitrogen fertilizer had significant effect $(\mathrm{P}=0.001)$ on maize seed phosphorus content. Maize plots applied with nitrogen fertilizer had significantly $(\mathrm{P}<0.05)$ higher seed phosphorus content of $0.52 \%$ than maize plots without nitrogen fertilizer application. Maize seeds phosphorus content was significantly affected $(\mathrm{P}<0.001)$ by season effect. Maize seeds harvested during $2012 / 13$ planting season had significantly $(\mathrm{P}<0.05)$ higher phosphorus content of $0.58 \%$ than maize seeds harvested during 2011/12 planting season. Maize seeds phosphorus content was significantly affected $(\mathrm{P}<0.001)$ by the interaction of site $\mathrm{x}$ season. 
Table 5. The interaction effects of cropping system, nitrogen fertilizer, site and season on maize seed phosphorus content in percentages

\begin{tabular}{lllllll}
\hline \multirow{2}{*}{ Cropping system } & \multirow{2}{*}{ Site } & \multicolumn{2}{c}{ N-fertilization } & & \multicolumn{2}{c}{ Zero-N } \\
\cline { 7 - 7 } \cline { 5 - 6 } \cline { 5 - 6 } Intercropping & & $2011 / 12$ & $2012 / 13$ & & $2011 / 12$ & $2012 / 13$ \\
& Potch & 0.42 & 0.68 & & 0.32 & 0.66 \\
& Rust & 0.48 & 0.61 & & 0.53 & 0.60 \\
Monocropping & Taung & 0.35 & 0.66 & & 0.39 & 0.52 \\
& Potch & 0.33 & 0.65 & & 0.28 & 0.55 \\
\multirow{2}{*}{ Rotation } & Rust & 0.49 & $0.49 \mathrm{j}$ & & 0.48 & 0.41 \\
& Taung & 0.43 & 0.64 & & 0.41 & 0.50 \\
& Potch & 0.40 & 0.79 & & 0.32 & 0.58 \\
SEM & Rust & 0.50 & 0.43 & & 0.50 & 0.52 \\
LSD $(0.05)$ & Taung & 0.40 & 0.61 & & 0.45 & 0.51 \\
\hline
\end{tabular}

Zero-N = Zero nitrogen fertilizer, Potch $=$ Potchefstroom, Rust $=$ Rustenburg, SEM = standard error of means, $\mathrm{LSD}=$ least significant difference.

\section{Discussion}

\subsection{Maize Seed Oil}

The higher maize seed oil content at Potchefstroom and Rustenburg might have been attributed to the soil type. Shen et al. (2010) reported that maize seed oil content is determined by the oil concentration in the embryo, embryo size and oil in the endosperm. Maize seeds collected from those two locations had large grain size with large embryos. The differences in oil seeds across the locations corroborates the findings by De Geus et al. (2008) who reported that oil content was affected by location and genotype. Their findings revealed that oil content of seeds produced in a low input system was significantly higher than in conventional systems in both years of production. Maize seed oil content that was affected by the interaction effect of cropping system $\mathrm{x}$ site $\mathrm{x}$ nitrogen $\mathrm{x}$ season contributed towards significant of this study on maize grain quality improvement, since such interaction effect on maize seed was not reported previously. The study conducted by Riedell et al. (2009) indicated that year had no significant effect on kernel oil concentration and there were no significant $\mathrm{N}$ input $\mathrm{x}$ rotation interactions for kernel oil concentration in their study. The study conducted by Esmailian et al. (2011) also found interaction of irrigation $\mathrm{x}$ fertilizer treatments to have no significant influence on maize oil content.

\subsection{Maize Seed Protein}

The difference in maize seed protein across the sites contradicts the findings by De Geus et al. (2008) who reported that the protein content among genotype significantly differed for both years and in both farming system, but the protein content was not significantly different between locations. The higher seed protein content under nitrogen fertilizer treated plots corroborates the findings by Da Silva et al. (2005), who reported that nitrogen application at silking also increases kernel crude protein content up to the application of $100 \mathrm{~kg} \mathrm{~N} \mathrm{ha}^{-1}$. This response showed that $\mathrm{N}$ applied during flowering was taken by the plant and accumulated in grains. They also indicated that possibility of increasing grain protein content with late $\mathrm{N}$ site dressing is reducing kernel susceptibility to breakage at harvesting. The difference in maize seed protein across the season corroborate the findings by Szmigiel (1998) who emphasized that protein content in grain is influenced by changes in weather condition during the vegetation period of maize. It was showed that the highest protein content in maize grain is obtained in dry and warm years, while in years of abundant precipitation high yields of grain were obtained at the lower protein content. The higher maize seed protein content at Taung was not expected in this study, due to sandy soil of that location. This finding implies that, it is possible to obtain high maize seed quality from sandy site, if good climatic conditions and supplementary irrigation are available during vegetative and reproductive stage of maize plant. Maize seeds protein content that was affected by the interaction effect of site $\mathrm{x}$ nitrogen and site $\mathrm{x}$ season was regarded as critical finding of this study, since such interaction effect on maize seed protein 
were not reported previously. The study by De Geus et al. (2008) revealed that location and location x genotype interactions had no effect on protein content suggesting that selection for high protein can be done in either conventional or low input cropping system.

\subsection{Maize Seed Starch}

The differences in soil types across the locations contributed to differences in maize seed starch content in this study. This agrees with similar findings by Wilkes et al. (2010) who reported that the soil type had the biggest impact on both protein and starch content, with the grains from grey vertosol soil having higher total insoluble and soluble protein contents and lower starch content. Starch content differed across the locations since quality of grain depend on interplay between the genetic characteristics of the plant and external factors that influence plant growth such as climate, soil and management practices. In this study, the different starch content among sites contradicted the findings by Buresova et al. (2010) who indicated that starch content was significantly affected by cultivar and year. They indicated that starch content was not significantly influenced by growing variant or site. The starch content of maize grains in this study differed across the seasons and this corroborates the findings the findings by Buresova et al. (2010) who reported that starch content was significantly affected by weather during growing season. They indicated that warm weather during the growing season had a significant positive effect on starch content. This explains the reason of high starch at Potchefstroom due to high temperature during planting and vegetative growth of maize. In this study, the interaction of nitrogen $\mathrm{x}$ season was found to have significant effect on seed starch content while the findings by Riedel et al. (2009) reported that, no significant $\mathrm{N}$ input $\mathrm{x}$ rotation interaction for kernel starch.

\subsection{Maize Seed Phosphorus}

The higher maize seed phosphorus content under rotational and intercropping might have been attributed to improved soil structure by accompanying cowpea. The higher phosphorus content under intercropping system agrees with similar findings by Biareh et al. (2013) who revealed that intercropping culture had significant effect on phosphorus content. They indicated that the system with $100 \%$ corn $+15 \%$ of bean ratio treatment with mean of $0.55 \%$ had the most phosphorus content in grains. The high phosphorus content of maize seed under $\mathrm{N}$-fertilizer treated plots may have been attributed to increased uptake of $\mathrm{N}$ by maize. Thiraporn et al. (2008) reported that weight of kernel phosphorus increased slightly with increasing rates of $\mathrm{N}$ fertilizer. The influence of nitrogen fertilizer on maize seed phosphorus content was also reported by Tarighaleslami et al. (2013), that different level of nitrogen fertilizer treatments had significant effect on phosphorus of seed and maximum phosphorus of seeds was gained by utilization of $180 \mathrm{~kg} \mathrm{ha}^{-1}$ of nitrogen fertilizers. Maize seeds phosphorus content that was affected by interaction effect of site $\mathrm{x}$ season contributed towards significant of this study on quality improvement of maize. The findings by Tarighaleslami et al. (2013) indicated that phosphorus of seeds was significantly affected by the interaction of irrigation and application of nitrogen fertilizer treatment. Riedel et al. (2009) reported the significant $\mathrm{N}$ input $\mathrm{x}$ rotation interactions for maize kernel phosphorus.

\section{Conclusions}

In this study, site as factor played a vital role on quality of maize seeds. Maize seeds collected at site with high clay soil content (Potchefstroom and Rustenburg) had high oil and starch content as compared to site with high sand. It was found that, maize seeds collected at site with high sand had higher protein content. It is then assumed that, soil type might have not been the only factor affected maize seed quality. The difference in seed quality across the site might have been affected by other climatic factors such as rainfall and temperature. The inclusion of legume on cropping system as intercrop or rotated with maize increases maize phosphorus content. The application of nitrogen fertilizer increases maize seed protein and phosphorus content. Maize seed protein, starch and phosphorus content depend on the season. The interaction of site $\mathrm{x}$ season played a significant role on this study, since it affected maize seed oil, protein and phosphorus content.

\section{References}

Amanullah, R. A., Khatta, K., \& Khalik, S. K. (2009). Plant density and nitrogen effects on maize phenology and grain yield. Journal of Plant Nutrition, 32, 246-260. http://dx.doi.org/10.1080/01904160903308168

Baker, D. E., Jarrel, A. E., Marshall, L. E., \& Thomas, W. I. (1970). Phosphorus uptake from soils by corn hybrids selected for high and low phosphorus accumulation. Agronomy Journal, 62, 103-106. http://dx.doi.org/10.2134/agronj1970.00021962006200010033x

Biareh, V., Sayfzadeh, S., Daneshian, J., Yousefi, M., \& Shiriyan, M. (2013). Evaluation of qualitative traits of corn grains under intercropping of corn and bean systems. Journal of Novel Applied Sciences, 2(2), 929-933. 
Botha, A. D. P., Snyman, H. G., Hahne, H. C. H., Prinsloo, A. L., Steenkamp, C. J., \& Duplessis, D. P. (1968). Eienskappe van die gronde van die navorsings institute vir Tabak. Tegniese Mededeling 74. Rustenburg: Department van Landbou-Tegniese Dienste.

Boyer, C. D., \& Shannon, J. C. (1987). Carbohydrates of the kernel. In S. A. Watson \& P. E. Ramstad (Eds.), Corn: Chemistry and technology (pp. 253-272). St Paul, Minn, USA: American Association of Cereal Chemistry. http://dx.doi.org/10.1016/0008-6215(87)80153-2

Buresova, I., Sedlackova, I., Famera, O., \& Lipavsky, J. (2010). Effect of growing conditions on starch and protein content in triticale grain and amylode content in starch. Plant Soil and Environment, 56(3), 99-104.

Copeland, L. O., \& McDonald, M. B. (2001). Principles of seed science and technology (4th ed.). Kluwer. Academic publishers, Boston, MA. http://dx.doi.org/10.1007/978-1-4615-1619-4

Da Silva, P. R. F., Strieder, M. L., Da Silva-Coser, R. P., Rambo, L., Sangoi, L. Argenta, G., ... Da Silva, A. A. (2005). Grain yield and kernel crude protein content increases of maize hybrids with late nitrogen $\begin{array}{lllll}\text { side-dressing. } & \text { Scientia Agricola } & \text { (Piracicaba }\end{array}$ http://dx.doi.org/10.1590/S0103-90162005000500014

De Geus, Y. N., Goggi, A. S., \& Pollak, L. M. (2008). Seed quality of high protein corn lines in low input and conventional farming systems. Agronomy for Sustainable Development, 541-550. http://dx.doi.org/10.1051/agro:2008023

Eskandari, H., \& Ghanbari, A. (2009). Intercropping of maize (Zea mays) and cowpea (Vigna sinensis) as whole-crop forage: Effect of different planting pattern on total drymatter production and maize forage quality. Notulae Botanicae Horti Agrobotanici Cluj-Napoca, 37(2), 152-155.

Esmailian, Y., Ghanbari, A., Babaeian, M., \& Tavassoli, A. (2011). Influence of organic and Inorganic fertilizers and waste water irrigation on yield and quality traits of corn. American Eurasian Journal of Agricultural and Environmental Sciences, 10(4), 658-666.

Farshadfar, M., Amjadian, M., \& Dabiri, S. (2012). The effect of intercropping (corn and soybean) on vigour of seed corn. Annals of Biological Research, 3(8), 3962-3967.

Gautam, P., Gustafson, D. M., \& Wicks III, Z. (2011). Phosphorus concentration, uptake and dry matter yield of corn hybrids. World Journal of Agricultural Sciences, 7(4), 418-424.

Gomez, K. A., \& Gomez, A. A. (1984). Statistical Procedures for Agricultural Research. John Wiley and Sons. New York.

Hammad, H. M., Ahmad, A., Khaliq, T., Farhad, W., \& Mubeen, M. (2011). Optimizing rate of nitrogen application for higher yield and quality in maize under semi-arid environment.

Idikut, L., Atalay, A. I., Kara, S. N., \& Kamalak, A. (2009). Effect of hybrid on starch, protein and yields of maize grain. Journal of Animal and Veterinary Advances, 8(10), 1945-1947.

Khogali, M. E., Ahmed, E. E. A., \& El-Huweris, S. O. (2011). Effect of nitrogen, intercropping with lablab bean (Lablab purpureus) and water stress on yield and quality of fodder maize. Journal of Science and Technology, 12(3), 55-66.

Lambert, R. J. (2001). High-oil hybrids. In A. R. Hallaver (Ed.), Specially corns (pp. 131-154). CRC Press, Boca Raton, FL.

Macvicar, C. N., De Villiers, J. M., Loxton, R. F., Verster, E., Lambrechts, J. J. N., Merryweather, F. R., ... Harmse, H. J. (1977). Soil classification. A binomial system for South Africa. Science Bull., 390, ARC-Institute for Soil Climate and Water, Pretoria.

Pule-Meulenberg, F., Belane, A. K., Krasova-Wadet, T., \& Dakora, F. D. (2010). Symbiotic functioning and bradyrhizobial biodiversity of cowpea (Vigna unguiculata L. Walp.) in Africa. BMC Microbiology.

Riedell, W. E., Pikul, J. L., Jaradat, A. A., \& Scumacher, T. E. (2009). Crop rotation and nitrogen input effects on soil fertility, maize mineral nutrition, yield and seed composition. Agronomy Journal, 101(4), 870-879. http://dx.doi.org/10.2134/agronj2008.0186x

Seebauer, J. R., Singletary, G. W., Krumpelman, P. M., Ruffo, M. L., \& Below, F. E. (2009). Relationship of source and sink in determining kernel composition of maize. Journal of Experimental Biology, 61(2), 511-519.

Shen, B., Allen, W. B., Zheng, P., Li, C., Glassman, K., Ranch, J., ... Tarczynski, M. C. (2010). Expression of 
ZmLECl and ZmWRL1 increases seed oil production in maize. Plant Physiology, 153(3), 980-987. http://dx.doi.org/10.1104/pp.110.157537

Stone, P. J., Sorensen, I. B., \& Reid, J. B. (1998). Effect of plant population and nitrogen fertilizer on yield and quality of super sweet corn. Agronomy New Zealand Journal, 28, 1-5.

Soil Survey Staff. (1999). Keys to soil taxonomy (8th ed.). Poca-hontas Press Inc., Blacksburg. Virginia.

Szmigiel, A. (1998). Wplyw kierunkow rzedow wzgledem stron swiata I rozmieszczenia roslin na plon ziarna kukurydzy. Zesz. Nauk. AR Krakow, 330(54), 239.

Tarighaleslami, M., Zarghami, R., Boojar, M. M. A., \& Koliai, A. A. (2013). Fatty acid, seed phosphorus and grain yield of maize as influenced by different irrigation and nitrogen fertilizers. Bulgarian Journal of Agricultural Science, 19(3), 479-484.

Thiraporn, R., Feil, B., \& Stamp, P. (2008). Effect of nitrogen fertilization on grain yield and accumulation of nitrogen, phosphorus and potassium in the grains of tropical maize. Journal of Agronomy and Crop Science, 169(1-2), 9-16. http://dx.doi.org/10.1111/j.1439-037X.1992.tb01180.x

Thomison, P. R., Geyer, A. B., Lotz, L. D., Segrist, H. J., \& Dobbels, T. M. (2002). Top cross high oil corn production: Agronomic performance. Agronomy Journal, 94, 290-299. http://dx.doi.org/10.2134/agronj2002.0290

Tsai, C. Y., Dweikat, I., Huber, D. M., \& Warren, H. L. (1992). Interrelationship of nitrogen nutrition with maize (Zea mays L.) grain yield, nitrogen efficiency and grain quality. Journal of Science and Food Agriculture, 58, 1-8. http://dx.doi.org/10.1002/jsfa.2740580102

Wambangu, P. W., Mathenge, P. W., Auma, E. O., \& Van Rheenen, H. A. (2012). Constraints to on farm maize (Zea mays L.) seed production in western Kenya: Plant growth and yield. ISRN Agronomy, 2012, 7.

Wilkes, M. A., Seung, D., Levavasseu, G., Trethowan, R. M., \& Copeland, L. (2010). Effects of soil type and tillage on protein and starch quality in three related wheat genotypes. Cereal Chemistry, 87(2), 95-99. http://dx.doi.org/10.1094/CCHEM-87-2-0095

\section{Copyrights}

Copyright for this article is retained by the author(s), with first publication rights granted to the journal.

This is an open-access article distributed under the terms and conditions of the Creative Commons Attribution license (http://creativecommons.org/licenses/by/3.0/). 